IRA-International Journal of Management \& Social Sciences

ISSN 2455-2267; Vol.04, Issue 03 (2016)

Pg. no. 602-611

Institute of Research Advances

http://research-advances.org/index.php/RAJMSS

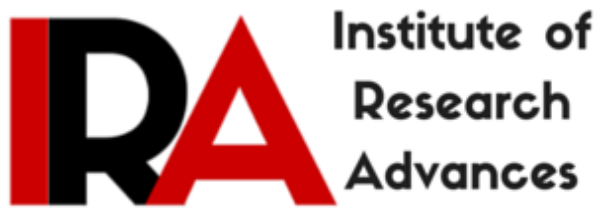

\title{
Traumatic Experiences of Nigerian Women: An Archetypal Representation in Adichie's Purple Hibiscus
}

\author{
Sadiya Abubakar \\ English Department, \\ Lovely Professional University, Punjab, India.
}

Type of Review: Peer Reviewed.

DOI: http://dx.doi.org/10.21013/jmss.v4.n3.p10

\section{How to cite this paper:}

Abubakar, S. (2016). Traumatic Experiences of Nigerian Women: An Archetypal Representation in Adichie's Purple Hibiscus. IRA-International Journal of Management \& Social Sciences (ISSN 2455-2267), 4(3), 602-611. doi:http://dx.doi.org/10.21013/jmss.v4.n3.p10

(C) Institute of Research Advances

\section{(cc) EY-NO}

This work is licensed under a Creative Commons Attribution-Non Commercial 4.0 International License subject to proper citation to the publication source of the work.

Disclaimer: The scholarly papers as reviewed and published by the Institute of Research Advances (IRA) are the views and opinions of their respective authors and are not the views or opinions of the IRA. The IRA disclaims of any harm or loss caused due to the published content to any party. 


\begin{abstract}
One of the most reprehensive subjugation among the so called cultural practices in Nigeria, is the oppression born out of widowhood, poverty is yet another great cause of trauma amongst many Nigerian women, especially among the no/low income earners, polygamy is as well seen to be a great causative agent of psychological disturbances amid Nigerian women chiefly in the northerners, and of course the recent Boko Haram terrorist acts that subjected many Nigerians to psychological distortion. Women in a patriarchal society like Nigeria, are treated with gender subordination which subjects them to experiencing indelible traumas. Trauma, however is today regarded as one of the leading causes of death. As such, its theorist put to light its various sources as: intimate partner violence, natural disasters, loss of loved one, sexual assault or any physical or mental wound, rape, and witness of violence. Chimamanda Adichie's Purple Hibiscus is an epitome of Nigerian women's difficulties and their traumatic experiences. This paper would explore the conformity of Trauma theory and the fictional presentation of Nigerian women's trauma in Adichie's Purple Hibiscus.
\end{abstract}

\title{
Introduction
}

It is generally believed that trauma theory is an amalgam of psychological studies with that of humanities. In literature especially, the theory is used in the study of the multiple dimension of characters' psyche. Susannah Radstone et al in Oxford Bibliographies opines that: "Trauma theory denotes a vibrant, interdisciplinary area of Western scholarship developed since the 1980s through cross-fertilization between psychology and the humanities" (Radstone 1). Another noteworthy aim of trauma narratives is to restructure cultural memory through individual perspectives, taking on testimonial traits to avert and bear witness against such repetitious horrors. (Laurie Vickroy 5). Elissa Marder, a professor of French and comparative literature at Emory University, in her essay Trauma and Literary Studies: Some "Enabling Questions" also observes that' In the late $20^{\text {th }}$ century, Cathy Caruth, a distinguished research professor of comparative literature and English is considered as one of the leading pioneers of trauma theory, she theorized the concept of trauma in the light of literature. That, literary texts are means through which the nature of trauma is revealed by its witnesses. . She argues that literature enables us to bear witness to events that can't be absolutely known and introduces us to experiences that might have otherwise stayed unspoken and unheard. Caruth powerfully and convincingly shows that despite the fact that certain kinds of events can't be completely understood, these events consequently become significant in diverse ways by being expressed to others and perceived by them. (Elissa 3 ).

\section{Historical Overview of Nigerian Women}

"There is no greater agony than bearing an untold story inside you." Maya Angleou

The pre historical situation of Nigerian women is in so many ways similar to that of Indian women. Women in the eastern, western and southern part of Nigeria are said to have indulged in certain practices which were abominable. They were directly or indirectly subjected to odious customary actions that were extremely horrible and terrific.

Like in India, women were and are still subordinated and discriminated against their male counterparts. In a patriarch dominated society like Nigeria, the social status of a woman is conceived as not only inferior to that of man, but also dependent on him clinging their rationale to cultural and religious reasons.

One of the most reprehensive subjugation among the so called cultural practices is the oppression born out of widowhood. Burning a widow alive alongside the corpse of her dead husband is India's old traditional method of handling widows where a woman's life is said to come to end at the death of her husband. In Nigeria however, the treatment is less intricate. She is not killed directly but indirectly; a widow suffers spiritual torture on the death of her husband, according to some old 
customs in certain parts of Nigeria. Her refusal to comply with these customs and heinous treatment would get her excommunicated from the society for she is assumed to have committed a grievous sin.

Another culturally controlled problem faced by women in the past in some parts of Nigeria is female circumcision or in other words genital mutilation; a long known barbaric act of ritual. It has been reported that in the eastern part of Nigeria, and even some part of Africa like Egypt, females undergo circumcision to initiate or get them prepared for wifehood. Like in other parts of the world, some tribes or communities perform this same unspeakable act. South America, east and south of Asia and north-eastern part of Africa are famous in such acts which effect pain and humiliation upon women.

Moreover, poverty is another great cause of trauma amongst many Nigerian women. Among the low income earners or those who earn below average, the trauma of hunger and inability to make available the basic needs have always added to the woes of the women in the past and present. A woman can live through days without food, security or shelter but she can't afford the same hardship if she has a child or children. The trauma of a woman is not only caused by what affects her directly but more importantly by the lack faced by her children. Therefore, some Nigerian women like other impoverished women around the globe are traumatized by inadequate financial stability to make ends meet. This is more annoying to women whose husbands habitually derelict their duties like Buchi Emacheta's Nnu Ego. The lady shoulders the responsibility of the whole family which her husband Nnaife abandons.

Polygamy is yet another root cause of psychological disturbances among Nigerian women especially the northerners. Jealousy is indeed a natural instinct; rivalry is an off spring of accumulated jealousy and hatred. Hence, vicious acts against one another among the co-wives of the same husband seem to have inflicted these women whose husbands practice polygamy. These vices result in nothing but physical or mental torture of one another and traumatic situations inflict the existence of all involved. The practice of having multiple wives is very common among Nigerians, Africans and Muslims across the globe. In fact, their religions permit the same and with the religious consent pocketed by the people in the society, patriarchic oppression and victimization are often ignored till the fury born out it has caused extensive damage. As a matter of fact, the quest for vengeance arises more rapidly when there is a condition or tendency of predilection by the husband.

In the same way, the most recent Boko Haram syndrome has subjected many Nigerian women to displacements, physical distortion and most of all psychological traumas. These women, as a result of series of terrorist attacks they encountered, lost their homes, jobs, children, husbands, relatives, loved ones etc. The trauma of witnessing such dreadful events is what Prof. Cathy Caruth described as extremely traumatizing. Female survivors of Boko Haram are immensely traumatized. Michelle Faul, the associated press of CTV News reported in the News article" Nigerian Women Rescued from Boko Haram Face Trauma and Stigma" that, the situation of women rescued from Boko Haram as "traumatizing and horrifying".

All in all, women in Nigeria are exposed to the risk of getting traumatized through situations like; domestic violence, limited social or religious sanctions, lack of social support and most importantly, cultural norms. David A. Oluwole in a research article on Patterns of Stress, Social Support and Mental Health among Nigerian Women venerated on the issue of trauma faced by Nigerian Women as:

"The effort to have and maintain a balanced mental health by the Nigerian women is thwarted by the presence of stress resulting from traumatic and rapid changes of life events".

Social activists and feminists who properly utilized their pens, voices, thoughts and actions to strive for women's rights in Nigeria are: Flora Nwapa, Buchi Emacheta, Zaynab Alkali, Chimamanda Adichie and few others. Recently, social activists expressed their views on the situation of a woman in Nigeria. Inspired by Chimamanda Adichie's essay, "Everyone Should be a Feminist," a book club 
ignited a discussion on what it looks like to be a woman in Nigeria; the country globally recognized as the most economically successful in Africa. Participants trended on twitter with the hashtag \#BeingFemaleInNigeria and the results were outstandingly remarkable. Reports: Clarissa - Jan Lim in a news article, 'Nigerian Women Share Experiences With Sexism On Twitter And The Results Are Harrowing'.

\section{Trauma of Domestic Violence}

In Chimamanda Adichie's Purple Hibiscus, the extent of domestic violence that prevails in the patriarchal society of Nigeria is shown or projected through the characters of Chief Eugene and his wife Mama (Beatrice). The plight of this woman is not limited to those occasional damages he caused her but the frequent battering she undergoes from him which has seem to become a normal phenomenon among the members of the lovely family.

It is quite surprising that Eugene, a man who has dedicated his life to fight for his people's political freedom from the threats of the nearly emerged government is a wife beater. His wife Mama seems to be a very calm, reserved and of repressive nature. She comes out as a woman always quiet, silently accepting his torture which he inflicts in the guise of religious ideology. Eugene's extreme devotion for the new religion drives him to adapt harsh and insensitive villainous measures in the treatment of his wife and children's religions mistakes. Otherwise he is not a fanatic. It is this excuse that is used by his wife Mama to tolerate Eugene's violence.

Mama, like other woman in Nigeria is traumatized as a result of physical and domestic violence which she experiences on various occasions from her loving husband. Eugene beats his life severely to the point of miscarriage for trying to thwart the will of God by putting her desires first. As a result, she is not only a victim of physical assault but also of mental breakdown which will be discussed later.

“...I heard the sounds. Swift, heavy thuds on my parents' hand-carved bedroom door...I sat down, closed my eyes and started to count... I stepped out of my room just as Jaja came out of his. We stood at the landing and watched papa descend. Mama was slung over his shoulder... There's blood on the floor, Jaja said. I'll get the brush from the bathroom. We cleaned up the trickle of blood..." (Adichie 33)

Mama also suffers unjust beatings from her husband for allowing Kambili her daughter to eat on the day of Eucharistic fast. Fathers cannot be as understanding as mothers can be, the feeling of attachment a mother has for her child is beyond human explanation. Kambili is ill and cannot fast for that reason, mama gives her some cornflakes to enable her take a pain reliever. Eugene, the violent father didn't demand for any explanation but went straight ahead to deal with them all for breaking God's rule and mama especially for supporting, disobedience of religious rule.

"It was a heavy belt made of layers of brown leather with a sedate leather-covered buckle. It landed on Jaja first across his shoulder. Then Mama raised her hands as it landed on her upper arm...he swung the belt on Mama, Jaja and me," (Adichie102).

Correspondingly, Mama loses another pregnancy to Eugene's violence. He beats her unscrupulously and also smashes a table on her belly. This is what some unlucky women go through in their matrimonial homes. The devilish egos men possess, drive them to do lots of crazy things. Eugene crosses miles to satisfy himself demonically whenever he loses his patience. Women who are married to hot tempered men experience the same trauma. In the Case of Mama, she has witnessed various forms of domestic violence as she cold vocally reports,

"You know that small table we keep the Bible,nne? Your father broke it on my belly... My blood finished on that floor even before he took me to St. Agnes. My doctor said there was nothing he could do to save it." (Adichie 248) 
These and many other forms of domestic violence are experienced by some Nigerian women. Many other writers have highlighted this problem; that have plagued Nigerian women in their works for instance Buchi Emacheta's Joys of motherhood remains a good example to illustrate the plight of women in Nigeria where Nnu Ego the protagonist of the novel undergoes extreme battering from her first husband for her inability to bear him child.

\section{Trauma of Social Forces}

The trauma of being a widow is heightened, when the society tends to interfere in family matters, the shattering situations grow worse rather than better. In reality a bereaved person on losing a spouse is actually at the weakest moment of one's life. At such a time the loss of a loved one, especially a spouse, surely leaves one with an emotional void and feelings of insecurity and pain seem to hit the survivor the most. On humanitarian grounds one is expected to be treated with more love, care and tenderness, to cover for the irreparable loss and make efforts in sustaining life and build endurance to survive the devastating situation. However, in some traditional parts of Africa, the reverse is the case. Widows are treated with harshness and cruelty; in some parts they are forced to drink the water used in bathing the corpse. "The belongings of the family are confiscated by members of the dead husband's extended family and the bereaved family is dispossessed of their inheritance" (Gloria 266). Adichie aptly portray the plight of such women in her novel purple Hibiscus.

Aunty Ifeoma, Chief Eugene sister is a courageous and hardworking lady who lost her husband to a ghastly car accident but is blamed for his death by his relatives. Despite her husband's absence, she still works tirelessly to make ends meet for their three children. The society she finds herself in, didn't applaud her for her efforts but rather, provoke her patience by accusing her of hiding some of her husband's wealth. "I don't have the strength for Ifediora's family right now. They eat more and more shit every year. The people in his Umunna said he left money somewhere and I have been hiding it". (Adichie74)

In the same way, this poor lady is not only disserted by her late Husband's family but also accused of killing him. "Last Christmas one of the women from their compound even told me I had killed him" (74) what could be more traumatic than these? Although Ifeoma remains strong and assertive in spite of all the outrageous accusations laid against her. Her trauma is repressed and veiled like that of Mrs. Gupta and Mrs. Bandaris of Rupa Bajwa's The Sari Shop.

Ifeoma is a woman who refuses to compromise her standards for favors from her brother. Though she is needy and seriously deserves external support. She chooses to remain herself rather than dancing to the tone of her brother chief Eugene. In a discussion with her sister in-law, Beatrice, she reveals:

"Have you forgotten that Eugene offered to buy me a car? ... But first he wanted us to join the Knights of St. John. He wanted us to send Amaka to convent school. He even wanted me to stop wearing makeup! I want a new car, nwunye $m$, and I want to use my gas cooker again and I want a new freezer and I want money so that I will not have to unravel the seams of Chima's trousers when he outgrows them. But I will not ask my brother to bend over so that I can lick his buttocks to get these things." (Adichie 95).

Likewise, the role played by society in heightening women's traumatic experiences is apparent in Mama's case. The so called Umunna which her husband, chief Eugene belongs to asks him to take another wife, all because he is rich and has just two children; which according to them is unworthy of a man like him. Without considering the feelings of his wife, they push many women to him and try to kindle the desire of having an additional wife on him. Beatrice reports in a conversation with Ifeoma. "Umunna will always say hurtful things. Did our own Umunna not tell Eugene to take another wife because a man of his stature cannot have just two children?" (Adichie 75)

Mama receives threats from their relatives and even the society they belong to. Just like Flora Nwapa's Efuru, whose husband was talked into marrying other wives because of her inability to 
reproduce. As a result of this threat, Mama is compelled to endure the abusive nature of her husband, she is automatically muted and deprived of wings to excel. She therefore has to play by the rule, otherwise someone else would take over from where she has stopped.

"Where would I go if I leave Eugene's house? Tell me where would I go? ... Do you know how many mothers pushed their daughters at him? Do you know how many told him to impregnate them even, and not bother paying a bride price?" (Adichie 123).

This is the extent to which society goes in supporting male dominance in a society like Nigeria's. the society remains silent and had people not shown countenance to such outrageous practices men would have been much more well behaved than they appear to be. Mama is thus traumatized not only due to direct attack from Eugene but also by the salient role the society plays in her marital life. Gloria opinions that,

"The phallocentric notion that a woman must have many male sons in order to be valued culturally makes Beatrice to feel insecure. The villagers believe that a man with Eugene's wealth and position in the society should not have just two children. This belief contributes to Beatrice's trauma after the second miscarriage."(Gloria 268)

Eugene is the wheel behind Mama's miscarriages but the society never say anything in regards to this, all they could do is, make noise and gossip about her inability to produce more children. Instead of questioning his cruel and violent behavior, the society blames Mama for not being able to give him as many children as he deserves. In this case, Mama's trauma becomes more vulnerable as the society is not in any way helpful. According to Martin and Hesselbrock quoted in Dejonghe et al. It is observed that social support improves the ability for flexibility among incarcerated women with histories of traumatic victimization.

Social support may have both a direct effect on mental health in the context of IPV [Intimate Partner Violence] and poor mental health outcomes. Similarly, tangible social support moderates the relationship between IPV\&PSTD [Posttraumatic Stress Disorder] symptoms. (Dejonghe et al 295)

\section{Trauma of Emotional Mishaps}

Every woman has a wish and a dream, and would feel thrilled when given the chance to make her dream come true or even at least, to fulfill her wishes. Mama is the wife who is deprived of the ability and sense of choice, she is reduced to an ordinary house wife not even a home maker, almost enslaved by her own husband, in her own legal matrimonial home. This is the height of masculinity and sense of dominance men exhibit in a patriarchal society like Nigeria. Many women like Mama have, and are suffering from the trauma of repressed emotions.

When Eugene asked her to join him in visiting Father Benedict, she decides to remain in the car because she's pregnant and not feeling well as a result, noticing his facial and gestural reaction, she immediately changed her mind and manages to join him reluctantly. Later at home, he beats her for that, for expressing her choice, for feeling sick, for not obeying before complain. Eugene reveals his inability to tolerate and accommodate her illness because he values religion more than his wife's health and happiness.

In the same way, Mama is deserted by her loving husband when she needed him the most. Women are naturally strong at heart but very little things that seem unimportant tend to break them down and hence, they become vulnerable to psychological trauma. Eugene beats Kambili, their daughter into fainting, it is only Mama who stayed with her in the hospital. She stood alone with the unconscious girl waiting for her recovery. Until Kambili recovers to consciousness, Mama has been waiting alone and idle in the hospital room. At this crucial moment, Eugene's physical presence is more than necessary. But he abandons her when his presence means and matters a lot to her, in as much as his 
absence could create a vacuum for depression, fear and internal turmoil, considering the situation. Likewise, Flora Nwapa's Efuru gets deserted by her husband for not being productive. He flees away and marries another woman after all the sacrifices she has done for him. The plight of Efuru and Mama is an allegory of Nigerian women's trauma, where women are maltreated for trivial reasons. Efuru isn't only abandoned by her first husband but also maltreated by her second husband.

Similarly, a mother's love for her biological child would forever remain a misery. Like mentioned earlier, it exceeds the human reasoning and thus, should remain impermeable. When a child is hurt, the mother gets affected directly or indirectly and share the pain with the child. There is an attachment between the two which only God knows how. Mama not only suffers Eugene's direct assault on her but also, the pain of his ill-treatment and cruelty that he inflicts upon her children. Eugene beats up the children for committing little or minor mistakes. For instance,

"He poured the hot water on my feet, slowly... The pain of the contact was so pure, so scalding, I felt nothing for a second. And then I screamed...

...Mama had come inside the bathroom. Tears were running down her face. Her nose was running, too... She mixed salt with cold water and gently plastered the gritty mixture onto my feet." (Adichie 194-195)

Eugene used boiled water to scald their feet for going against his rule, their crime is why they didn't tell him over the phone that his heathen father is living under the same roof with the Christian them. He kicked and beat the hell out of Kambili until she goes unconscious for keeping his heathen father's portrait, he beat and breaks Jaja's little finger for not answering two questions properly in a test, he flings missal against Jaja for missing communion. All these and few other incidents culminated and affected the mental state of Mama, they accumulated and formed a permanent scare in her mind which further triggers her trauma. Alameda County Trauma Informed Care, refers to trauma from a psychological perspective to describe experiences that are emotionally painful and distressing and that overwhelms an individual's capacity to cope

Kambili is fifteen years old now, Mama has a dying wish to have another child but Eugene's violence wouldn't let her nurture the pregnancy till delivery. She had miscarriage six years back at the time she tells Kambili of her current pregnancy, which also gets destroyed after series of beatings from her husband. Also, she lost another six weeks old pregnancy to Eugene's torture as he smashed a table on her tummy. These incident are more than enough reasons to reduce someone to mental wrecks. Adichie flawlessly describes mama's plight.

"She cried for a long time she cried until my hand clasped in her felt stiff. She cried until Aunty Ifeoma finished cooking the rotting meat in a spicy stew. She cried until she fell asleep, he heads against the seat of the chair. Jaja laid her on a mattress on the living room floor" (Adichie 249)

\section{Trauma of Oppression}

As far as trauma is concerned, there are various forces behind its emanation as well as disposition of experiences. Referring back to Dejonghe, we are understanding trauma as the act of witnessing or partaking an event which involves threats "to life or physical integrity that results in feeling of fear, helplessness or horror." (Dejonghe 294). Therefore, this research would not only consider domestic violence, emotional ills or societal troubles as traumatic but also subjugation and oppression from distant and external forces. Threats to life and physical integrity are seen in all facets of oppression especially, that, by tyrannical leaders. Nigeria as a nation, witnessed various kinds of oppressive leadership after gaining colonial independence from mother England in 1960. Several military rules afflicted the country "between 1966 and $1999 \ldots$ apart from a short-lived return to democracy between1979-1983." (Wikipedia) 
The effects of these military rules went beyond economic, political, social or religious, to psychological and spiritual due to its disastrous nature. As a result of various military coups that handed Nigeria's fate from one tyrant to the other, Nigeria's economy fell drastically and thus, increase in poverty, disease, urban dislocation, crimes, institutional decay. (Ihonvbere 196). As a consequence there were lots of unquestionable and unjust loss of lives, intense destitution and adversity of penury. The victims of these misfortunes are thereby inevitably thrown into trauma.

In Purple Hibiscus however, the upshot of military rule among other calamities, claimed Ade Coker's life through a letter bomb that blew him up right in front of his wife Yewande, leaving her forever traumatized. It devalued Nigeria's economy, causing fuel scarcity, inflation of food prices among others, automatically sent a lot of people to poverty. Ifeoma isn't only a victim of these, but also, of occupational threats from the dictating government. Therefore, she becomes gravely traumatized for threats to her life and physical integrity.

In contrast, Mama's trauma is unlike that of Aunt Ifeoma and Yewande Coker, Mama's victimization results from Eugene's transfer of aggression. Being at the receiving end of Eugene's grief, as caused by the tyrannical military regime which closes down his wafer factory, claims the life of his reporter (radio station) and also rendered lots of people jobless to which he has to shoulder their responsibility. Mama reports; "Eugene has not been well. He has been having migraines and fever... He is carrying more than any man should carry. Do you know what Ade's death caused him? It is too much for one person." (Adichie 250) Thus, Eugene shifts his anger on the poor Mama, beats her up devilishly, torture her emotionally; ultimately causing her to be earnestly traumatized. "Her face was puffy from crying and her lips were cracked, with bits of discolored skin peeling off." (213). These or more, are what some Nigerian women underwent during the days of military rule in Nigeria.

"In Purple Hibiscus by Chimamanda Adichie, there is a critical presentation of the oddities in Nigeria as well as Africa in general, as the continent trudges in the biting tyrannical trauma of the military and anarchical leaderships." (Anthony 119)

\section{Trauma Management Strategies}

"They did an autopsy... They have found the poison in your father's body... I started putting poison in his tea before I came to Nsukka." (Adichie 290) Mama finally poisoned Papa to death. She resorts to killing her husband to terminate the oppression and cruelty she suffers from him. This is a commonly used strategy adopted by traumatized women to do away with the force behind their trauma. Just like Maya of Anita Desai's Cry the Peacock, a neurotic character who murders her husband, Gautama to make worthy her survival. Mama severely suffered several tortures from her husband, being "Excluded from access to forms of power that will protect herself and her children, Beatrice resorts to violence herself" (Stobie 427).

For Mama, rather than fighting against her greatest fear, she simply takes a flight out of the terrific situation by murdering the causative agent of her devouring trauma, her beloved husband. Jesse Emery rightly puts it that,

"The neocolonial, patriarchal oppression of Beatrice leads her to revolt, but violence is the only method of revolution she can use... She slowly poisons Eugene as a reaction to the physical and emotional abuse he has caused." (22)

Aunt Ifeoma also flew away from the devastating situation. Rather than staying in Nigeria to continue to suffer the hardships caused by the tyrants, she relocates to America to save herself the trouble that would continue to emanate into trauma. 


\section{Conclusion}

This paper has explored the traumatic experiences of Nigerian women in its various facets as represented in Chimamanda Ngozi Adichie's Purple Hibiscus. While it incorporated trauma theory, it examined women's response(s) to trauma caused by domestic violence, sexual assault, penury, wounded emotions, oppression of tyrannical leaders and that of social forces. It has as well identified strategies employed by women to manage violence of partner or societal inflicted trauma. The findings of this research however, is that there are relatively less trauma centers in Nigeria. This lack of sufficient trauma care centers allows trauma to coexist among human psyche and exposes its victims to endure a longer duration of suffering. In Nigeria, most victims of recent series of bomb blasts and other forms of terrorists' attacks are still wrapped up in sacks of trauma, because they have been provided with zero or insufficient care. Most trauma personnel are however, strictly medically oriented. Other forms of trauma care services like that of molested or battered women are rarely available.

Apart from trauma centers, trauma management techniques that could be helpful are: social awareness on trauma management; the government, through education system or other friendly means, should educate and make people aware of the bad consequences of trauma and how to give a first-hand help to a trauma victim. Also, a very sound and effective social support for women should be created to elevate the derogatory status of women in the society. By way of this, there would be less risk of trauma among women. As of today, trauma has been rated number five among death causing illnesses. Thanks to literature for unveiling such issues of trauma and letting it to penetratingly reach out to the world through narration.

\section{Bibliography}

Adichie N. Chimamanda. Purple Hibiscus. UK: Harper Perennial, 2004. Print.

Bloom, Sandra L., and M.D. Trauma Theory Abbreviated. Departement of Human Services, Victoria, Australia. N.p. 1999. Web. 01 Nov, 2015. http:// www. dhs. Vic .gov. au/data / assets / pdf file /0005/587966/trauma theory abbreviated sandra bloom. pdf

Caruth, Cathy. Unclaimed Experience trauma, Narrative and History. London: The John Hopkins University Press, 1996. Web.

Cheryl, Stobie. Dethroning The Infallible Father: Religion, Patriarchy and Politics In Chimamanda Ngozi Adichie's Purple Hibiscus. Oxford Journals. N.p. 09 Nov,2010. Web. 25 Oct, 2015. http: // litthe. Oxford journals. Org /content /24/4/421 .short?rss =1 \&ssource=mfr

Clarissa Jan Lim Nigerian Women Share Experiences With Sexism On Twitter And The Results Are Harrowing. July 1, 2015. NA. Web. April 19, 2016. http://aplus.com/a/nigerian-womenshare-their-experiences-with-sexism-on-twitter

DeJonghe E. S. et al. Women survivors of intimate partner violence and post-traumatic stress disorder: Prediction and prevention. Bioline International. N.p. Oct, 2008. Web. 30 Oct, 2015. http://www.bioline.org.br/pdf?jp08102

Diara, Tunca. Biography. The Chimamanda Ngozie Adichie Website.university of Liege. NA. web. 25 Oct, 2015. http://www.13.ulg.ac.be/adichie/cnabio.html

Elissa, Marder. Trauma and Literary Studies: Some "Enabling Questions". Reading On: A Journal of Theory and Criticism. N.p. 01 Jan, 2006. Web. 01 Nov, 2015. http: // read ingon. library. emory. Edu /issue1 /articles /Marder /RO\%20-\% $202006 \%$ 20-\% 20 Marder.pdf 
Felman, Shoshana and Dori Laub, MD. Testimony Crises of Witnessing in Literature, Psychoanalysis and History. Routledge. Newyork. 1992. Web.

Fwangyil, A. Gloria. A Reformist - Feminist Approach to Chimamanda Ngozi Adichie's Purple Hibiscus. African Research Review. 5. May 2011. 261-274. Web. Oct. 2015.

Ihonvbere O. Juias. Are Things Falling Apart? The Military and Crisis of Democratization in Nigeria. The Journal of African Studies. 1996. 34, 2. Web. April 22, 2016.

Jesse, Emery. Decolonizing Patriarchy: The Female Voice in Chimamanda Adichie's Purple Hibiscus and Tayeb Salih's Season of Migration to the North. UVA-DARE. N.p. 29 June,2012. Web. 25 Oct, 2015.

Military Coups in Nigeria. Wikipedia The Free Encyclopedia. Web. April 09, 2016. http://en.wikipedia.org/wiki/military-coups-in-nigeria

Ogungbo, Biodun et al. Crying out for Nigeria's ignored trauma patients. Nigerian Health Journal. Web. Sept. 15, 2011. http://nigerianhealthjournal.com/?p=1356

Oha, C. Anthony. Beyond the Odds of the Red Hibiscus: A Critical Reading of Chimamanda Adichie's Purple Hibiscus. J of Pan African Studies 1. 9. 2007. 199-211. Web. Oct, 2015. 